4. Dr. Tony Bates. Building an effective learning environment. URL: https://www.tonybates.ca/2016/02/22/building-an-effective-learningenvironment/

DOI https://doi.org/10.30525/978-9934-26-039-1-97

\title{
INTERACTIVE TECHNOLOGIES IN FOREIGN LANGUAGE LESSONS AS A WAY OF CRITICAL THINKING FORMATION FOR STUDENTS OF NON-LINGUISTIC UNIVERSITIES
}

\author{
Nykyporets S. S. \\ Lecturer at the Department of Foreign Languages \\ Vinnytsia National Technical University \\ Vinnytsia, Ukraine
}

The modern world cannot be imagined without the World Wide Web, it is even more difficult to imagine a teenager who does not use social networks for daily communication. The huge popularity of social networks has created new opportunities for mastering foreign languages. Today, communication with native speakers, correspondence with peers from other countries, the creation and implementation of joint telecommunication projects, participation in text and voice chats, reading hypertext information in a specialty, using online dictionaries and much more has become an everyday reality. Advances in technology mean that language practice that fosters language acquisition, communication competence and motivation is available to learners. However, as a result of the rapid development of technology, a need arose for lifelong education: knowledge is aging so quickly that you have to constantly retrain. Learning is becoming one of the main skills. And it is this skill that is acquired when learning a foreign language using computer technology.

The development of critical thinking becomes very relevant in times of intense social change, when it is impossible to act without constant adaptation to new political, economic and other circumstances, without the effective solution of problems, substantial part of which is unpredictable. That is why the vital need for critical thinking for our Ukrainian educational system is obvious. Only in this way can we think about the development of democracy in accordance with the requirements of world society.

When using interactive methods in English classes, a number of problems arising among students can be noted: the inability to express their own opinions; fear of being mocked by other students; evaluate the opinions of 156 
others objectively; to compromise in decision-making; it is difficult for students to be mobile, to perceive different approaches, to use relevant methods of work. Therefore, interactive learning of English should encourage students to become active participants in the learning process, to involve them in the free expression of their own opinions, possible defence of their position in solving educational problems, to develop their skills of independent problem solving [1, p. 1430].

The purpose of using interactive methods in English classes is to develop students' initiative, independence, critical thinking and creativity in decisionmaking. In the conditions of interactive learning, the teacher and the student are in equal partnership: they jointly determine the purpose of the activity, object, subject, methods, means of activity, learning objectives. During such a joint search, an exchange of thoughts, knowledge, methods of activity is carried out, as a result of which there is a reflection, evaluation of the results obtained in educational activities. All this contributes to the formation of their own position of an active subject of learning, critical thinking, the ability to work independently. Thus the teacher acts not only as a source of the information, but also the organizer of all educational work. It creates a favourable atmosphere of cooperation with students, helps them to be creative in the learning process in general and promotes the development of their ability to compare alternative solutions, to see atypical ways to solve educational problems.

Using multimedia technologies, the teacher can present information in a completely new and effective form, make it more complete, interesting and adapted to modern realities [2, c. 2115]. Multimedia empowers almost all of the student's senses by combining printed text, graphics, motion video, static photographs and audio recordings to create a «virtual reality» of true communication. There are a huge number of computer interactive programs for learning a foreign language. Let's consider the most common ones.

Program Professor Higgins. English without an accent! is a complete phonetic, lexical and grammatical multimedia training guide designed for those who want (regardless of their initial level of knowledge) to learn to understand spoken language and speak grammatically correctly. Learning is based on comparing your own pronunciation with the reference one, not only by ear, but also visually, according to the graphics on the monitor screen, which became possible thanks to the original technologies for highlighting and recognizing the sound parts of a word.

Anki is a program that makes it easier to remember information. The spaced repetition technique it uses is much more effective than traditional memorization methods. Using this program can significantly reduce the time 
spent on memorizing the material, or significantly increase the amount of learned information.

Multimedia technologies allow developing vivid and more interesting speaking exercises, it is also important that the assimilation of new information using multimedia technologies takes place in a playful way. The use of multimedia technologies allows students to independently prepare miniprojects of various topics and present them [3]. Interactive technologies create conditions under which the students feel their own success and intellectual competence, helping to form critical thinking. Here are some examples of methodological techniques and technologies aimed at developing critical thinking skills.

What's Your Rating? It is used to assess the proposed situation by comparing it with the standard of behaviour accepted in society. Students, assessing their own traits, habits, views, compare them with the standards of behaviour of others and designate the result of comparison on a scale of values.

Priority Ladder technology is used to match objects or phenomena in order to determine priorities. Students are encouraged to identify their own priorities among the proposed values and place them at the appropriate levels.

Human Bias Graph technology is aimed at identifying possible bias towards the proposed statements and assessing their own positions. Students decide what position to take in the proposed problem situations and reflect their agreement or disagreement with certain statements.

Milestones technology is aimed at determining the sequence of actions in the process of solving a specific problem situation. To do this, students build a plan for solving the problem step by step, justifying the chosen sequence.

The five-minute essay is a short story used at the end of the lesson to help students better understand their thoughts on the topic studied and to enable the teacher to analyze what is happening in the class on an intellectual level. The five-minute essay poses two tasks for the students: write what they have learned on the topic; ask a question: «What is left unclear.»

Fishbone technology. It got its name from the fact that its visual expression resembles a fish bone. It allows students to «break down» a common problematic topic of a number of reasons and arguments. The use of this technique will help students understand the importance of argumentation, and also that each problem is multilayered, may have several reasons that affect each other.

The use of these and other techniques creates opportunities for the formation of students' critical thinking skills associated with the ability to 
extract, process and use information from various sources, as well as present the results of its analysis in a concise form [4].

In the study of a foreign language using interactive methods, students develop the following skills:

- express their own opinions freely,

- analyze their own and other proposals,

- formulate questions clearly,

- compare your own beliefs with others,

- critically evaluate the opinions of others,

- defend their own positions and give arguments,

- formulate concise conclusions,

- find contradictions in facts and statements,

- conduct a detailed analysis of the learning situation,

- find a rational way to solve the problem.

Therefore, the organization of English language classes aimed at forming critical thinking of students is a step-by-step logical and systematic use of interactive teaching methods from simple to complex and includes: learning game techniques, expanding the use of game situations, elements of discussions, debates, summing up the lessons on the topic in a playful way. Skillful implementation of interactive teaching methods in learning a foreign language provides organized interaction between students and the teacher, students become active participants in the pedagogical process. They develop initiative, independence, creativity and critical thinking in educational activities.

Thus, the use of modern educational technologies allows us to organize the educational process more productively, effectively, interesting and information-rich. The use of new pedagogical technologies in the classroom proves that the process of teaching English can be viewed from a new point of view and master the psychological mechanisms of personality formation, achieving better results.

\section{References:}

1. Şahin Gökçearslan, Ebru Solmaz. Critical Thinking and Digital Technologies: Concepts, Methodologies, Tools, and Applications. Rapid Automation (pp.1407-1433). DOI: https://doi.org/10.4018/978-1-52258060-7.ch066

2. Leysan R. Kayumova, Marina A. Morozova. Using the Technology of Critical Thinking Development (CTD) as a Means of Forming Competencies of Students Majoring in «Life Safety». National Journal of Environmental and 
science Education, 2016. Vol. 11. № 8 P. 2113-2122. DOI: https://doi.org/ 10.12973/ijese.2016.582a

3. Jessica Mansbach. Using technology to develop students' critical thinking skills. URL: https://dl.sps.northwestern.edu/blog/2015/09/usingtechnology-to-develop-students-critical-thinking-skills (date of application 16.02.2021)

4. Sammy Ekaran. 8 Ways To Improve Your Critical Thinking With Technology. URL: http://blog.whooosreading.org/8-ways-to-improve-yourcritical-thinking-with-technology (date of application 15.02.2021)

DOI https://doi.org/10.30525/978-9934-26-039-1-98

\title{
УНИВЕРСАЛЬНОСТЬ - КЛЮЧЕВОЕ ТРЕБОВАНИЕ СОВРЕМЕННОГО ОБУЧЕНИЯ ИНОСТРАННЫМ ЯЗЫКАМ
}

\author{
Парфимович О. В. \\ магистр, \\ преподаватель кафедры перевода \\ Донеикого института сочиального образования \\ 2. Киев, Украина
}

Шолохов А. В.

кандидат физико-математических наук, дочент кафедры прикладных информационных систем Киевского наџионального университета имени Тараса Шевченко 2. Киев, Украина

Современный мир предъявляет жесткие требования к выпускнику любого высшего учебного заведения, а, значит, есть над чем задуматься и что совершенствовать в системе обучения студентов старших курсов, чтобы они, выйдя из стен альма-матер, могли найти перспективную работу на конкурентном рынке труда.

Проанализировав функции, объемы, которые выполняют переводчики на предприятиях, в организациях, частных компаниях и бюро переводов, а также тематики, с которыми сталкивается переводчик даже в пределах одного предприятия, становится очевидным, что работодатель стремится получить универсального, а не узкоспециализированного работника. Поэтому для подготовки такого специалиста уже в процесс обучения в вузе необходимо введение аудиторных часов для 